Stony Brook University

Academic Commons

School of Marine \& Atmospheric Sciences

Faculty Publications

School of Marine \& Atmospheric Sciences

$9-2020$

\title{
A Return to State-Led Integrated Regional Planning? Emerging Approaches from Three U.S. States
}

\author{
Timothy Green \\ Clemson University, tgreen8@clemson.edu \\ Donovan Finn \\ Stony Brook University, donovan.finn@stonybrook.edu
}

Follow this and additional works at: https://commons.library.stonybrook.edu/somas_articles

Part of the Public Policy Commons, Urban, Community and Regional Planning Commons, and the Urban Studies and Planning Commons

(c) (†)

This work is licensed under a Creative Commons Attribution 4.0 International License.

\section{Recommended Citation}

Green, Timothy and Finn, Donovan, "A Return to State-Led Integrated Regional Planning? Emerging Approaches from Three U.S. States" (2020). School of Marine \& Atmospheric Sciences Faculty Publications. 9.

https://commons.library.stonybrook.edu/somas_articles/9

This Article is brought to you for free and open access by the School of Marine \& Atmospheric Sciences at Academic Commons. It has been accepted for inclusion in School of Marine \& Atmospheric Sciences Faculty Publications by an authorized administrator of Academic Commons. For more information, please contact mona.ramonetti@stonybrook.edu,hu.wang.2@stonybrook.edu. 
PRE-PUBLICATION DRAFT: Please cite from published version

A Return to State-Led Integrated Regional Planning? Emerging Approaches from Three U.S. States

Published online in State and Local Government Review on September 23, 2020:

https://doi.org/10.1177/0160323X20960212

\author{
Authors \\ Timothy Green, PhD \\ Lecturer \\ Department of City Planning and Real Estate Development \\ Clemson University \\ Box 340511 Clemson University \\ Clemson, SC 29634-0511 \\ tgreen8@clemson.edu \\ Donovan Finn, PhD \\ Assistant Professor of Environmental Design, Policy and Planning \\ School of Marine and Atmospheric Sciences \\ W0512 Melville Library \\ Stony Brook University \\ Stony Brook NY 11794-3352 \\ Donovan.finn@stonybrook.edu
}

\begin{abstract}
After decades of neglect, several U.S. states have increased support for regional development planning, creating new programs, organizations, and funding streams to support it. Analysis of programs in three states (New York, Michigan, and Indiana) shows similarities among them as well as contrasts with prior episodes of state-led regional planning. The new programs deliberately sidestep older regional planning organizations like COGs and RPCs in favor of new organizations with larger roles for the private sector and greater access to public funds. The resulting plans focus on individual projects within a pro-development agenda, but still have potential to coordinate action at a regional scale.
\end{abstract}




\section{Introduction}

In 2014, New York state awarded Hamilton County \$1.7 million to expand broadband access in rural areas. The grant was awarded through the state's Regional Economic Development Council (REDC) program, part of over $\$ 700$ million awarded statewide that year (New York State 2014). In late 2015 the Indiana Regional Cities Initiative ( $\mathrm{RCl}$ ) awarded $\$ 126$ million in matching funds to three winning regional plans that envisioned 100 diverse development projects representing more than $\$ 2$ billion in total investment, including riverfront development in Fort Wayne, a medical research center in downtown Evansville, and improvements to a technology park in South Bend (Indiana Economic Development Corporation 2020). From 2014 through 2019, Michigan allocated several million dollars per year through the Regional Prosperity Initiative (RPI) to incentivize the creation of new regional planning organizations that would bring together a diverse set of players including Metropolitan Planning Organizations (MPOs), Regional Planning Commissions (RPCs), Councils of Governments (COGs), and institutes of higher education, among others (Michigan Dept. of Technology, Management, and Budget 2020a). After decades of declining support for regional planning, this swell of investments in three very different states may be a sign of an emerging new trend for the U.S. reinvigorated and state-led regional planning organizations that channel significant investments across a range of development initiatives.

This paper outlines some key characteristics of those organizations through an analysis of three cases (in Indiana, New York and Michigan), and highlights some important ways in which they differ from regional planning organizations created in prior eras:

- The new organizations expand the power of the private sector at the expense of local elected leaders and older regional planning organizations.

- They have access to larger pools of funding and adopt a more pro-development approach driven by a focus on individual projects rather than attempting to shape development by influencing local regulation.

- They envision regional planning as a way to impact a broad swath of policy areas including housing, capital investment, education, and resource management.

After a brief review of the evolution of regional planning in the U.S., this article summarizes findings from the three states and discusses implications of this re-orientated and reinvigorated approach for the ongoing evolution of regional planning as well as governance more broadly.

\section{The Evolution of Regional Planning In the U.S.}

In the U.S., regional planning in metropolitan areas has been episodic. The term "regional planning" has been applied to a broad set of endeavors undertaken by very different types of organizations across varied scales using a variety of approaches (see Table 1; Friedmann and Bloch 1990; Friedmann and Weaver 1979; Weitz and Seltzer 1998; Seltzer and Carbonell 2011; Chapin 2012). The first government agency with regional planning authority, the Boston Metropolitan Improvement Commission, was created by the Massachusetts state legislature in 1902 (Meck 2002). Civic and business leaders spearheaded other early efforts such as the 1909 Plan of Chicago (Burnham and Bennett 1909), sponsored by the Commercial Club of Chicago, and 1929's Regional Plan for New York and its Environs (Committee on Regional Plan of New York and its Environs 1929), an initiative undertaken by a committee of civic boosters that eventually became the Regional Plan Association, which still exists today. The federal government was also an early supporter of regional planning through the creation of model legislation like the Standard City Planning Enabling Act (U.S. Dept. of Commerce 1928) as well as the encouragement of cooperation between states, most notably the 1933 creation of the Tennessee Valley Authority (TVA), a congressionally chartered corporation that has, over its lifetime, invested billions of dollars in large infrastructure to spur development in a relatively poor rural region (Hansen et al. 1990). 
PRE-PUBLICATION DRAFT: Please cite from published version

Table 1 - Common regional planning and development organizations referenced in this paper

\begin{tabular}{|l|l|l|}
\hline Name & Abbreviation & Mandate \\
\hline $\begin{array}{l}\text { Regional Plan(ning) Commission / } \\
\text { Regional Plan(ning) Council }\end{array}$ & RPC & State or inter-local \\
\hline Council of Governments & COG & State or inter-local \\
\hline Metropolitan Planning Organization & MPO & Federal and State \\
\hline Economic Development District & EDD & Federal \\
\hline
\end{tabular}

Note: For a more complete discussion, see Miller and Nelles (2020)

By 1937 there were 316 public metropolitan or county planning bodies in the U.S. (Meck 2002) in addition to numerous privately financed regional planning councils, but most of these lacked sufficient funding or statutory authority to regulate development or to engage in major projects. After a lull during WWII, the federal government became more directly involved with sub-state regional planning, typically by requiring regional coordination to qualify for large federal capital grants. Both the Federal Housing Act of 1954 and the Federal-Aid Highway Act of 1962 provided support for regional planning, and in the latter case required it in order to receive federal funds (Grigsby III 2003, Hanlon et al. 2009). The Public Works and Economic Development Act of 1965 created the Economic Development Administration and regional Economic Development Districts (EDDs) managed by "District Organizations" that are designated by the states and which often also serve as MPOs, RPCs or both. Later, the Office of Management and Budget's A-95 circular of 1969 gave regional agencies the authority to review a wide range of applications for federal assistance to assure regional consistency (Mogulof 1971).

The federal government's use of incentives to spur regional planning is a reaction to its limited authority to directly empower sub-state regional organizations under the U.S. Constitution. States have therefore been key players in the evolution of regional planning and governance, and most have empowered regional planning organizations one or more times over the years (Whisman 2013). The first of California's still powerful clean air districts was created in 1947, and by 1971 regional planning bodies were present in all of the (then) 247 metropolitan areas in the U.S., mostly as COGs or RPCs (Meck 2002).

Even in their heyday though, most regional organizations empowered by states suffered from weak and inconsistent political support from both state and local governments. In part this was because any powers granted to regional organizations necessarily limited those of states or municipalities (Morrill 1989; Rothblatt 1994; Frug and Barron 2008; Julnes and Pinder 1994). As a result, most had limited authority, in terms of taxing and regulation, compared with more established forms of local government such as cities and counties. Prominent exceptions like those in Portland, OR, Minneapolis, MN, and a brief statewide effort in Florida are the exceptions that prove the rule (Abbot 1997; Orfield 1997; Pelham 2017).

Instead, state-created regional planning organizations in the twentieth century drew much of their local support from their ability to secure federal funds. As those funds waned in the 1970's and 80's, the limited power of regional planning organizations declined further, with 30 percent of organizations disappearing between 1976 and 1989 (Wallis 1992). Those that remained often morphed from true regional planning organizations to fee-for service providers to other local governments (Bowman and Franke 1984).

Since the 1980s most states have shied away from state-wide support for regional planning organizations, though robust organizations persist in certain places like California's Sacramento Area Council of Governments and the Partnership for the San Joaquin Valley, in addition to the Portland and Minneapolis examples noted above (Dabson 2019). Some states have tried to coordinate local planning directly through mechanisms like State Development Plans (SPDs) (Lewis and Knapp 2012). Several types of newer civic-led organizations have also emerged. The most common of these are private sector-led regional economic development partnerships, some of which receive state support, and that primarily engage in business 
attraction with regional economic development planning as a secondary function (Olberding 2002, Green 2016). Other civic-led efforts like Envision Utah are focused exclusively on regional planning (Envision Utah 2016). The federal government also continues to fund pilot programs that promote regional planning such as the Workforce Innovation in Regional Economic Development (WIRED) program that incentivized coordinated regional planning between workforce training and economic development organizations (Renski 2009).

The end result of these decades of efforts by states, the federal government, local governments, and the civic sector is a patchwork of confusing, overlapping, and sometimes conflicting regional planning organizations in the U.S. There is no definitive listing of U.S. regional planning organizations, and many states have multiple types of regional entities with access to different funding streams, sometimes addressing similar issues but often across different geographies (Dabson 2019). For example, a COG or RPC may do regional planning but also serve as an MPO or EDD even if the two mandates have slightly different boundaries. As a result, getting a clear picture of regional organizations in the U.S. has proven difficult (Miller and Nelles 2020). Whisman (2013) cataloged the existence of 695 COGs/RPCs in 2013, and there were 408 MPOs in 2015 (Bureau of Transportation Statistics 2015), but as noted previously some organizations have multiple designations.

Interest in regional planning persists because the problems faced by sub-state regions cannot be addressed adequately by local governments alone. These include issues like inadequate multi-jurisdictional transportation systems, lack of open space, and disorderly development that motivated early regional planning advocates (Friedmann and Weaver 1979, Fishman 2000). Additionally, coordinating the provision of public services over larger regions allows for economies of scale (Abels 2014). More recently, concerns about ecological sustainability and resilience in the face of climate change (Wheeler 2000) as well as increased economic disparities and competition among regions has provided renewed interest in regional planning that integrates a wider set of policy domains and takes advantage of new institutional forms (Piro 2017). In this context of ongoing interest in addressing problems at the regional scale but with declining federal support for doing so, a renewed impetus for innovation has emerged at the state level.

\section{Study Design}

The cases presented here were identified through a nation-wide scan of state-led regional planning programs. The selected cases were chosen due to their relative newness and their contrast with older programs. The focus was on describing what Yin (2009) terms revelatory cases - those that explore and describe the emergence of a new phenomenon of interest. Accordingly, concerns about the representativeness of cases or the generalizability of the findings to other states were not central to this study.

The case study protocol involved collection of statutes, organizational reports and websites, media coverage, and occasionally published scholarly work relevant to each case. An extensive case report was prepared for each case which was then analyzed along a set of common parameters (Table 2). Cross-case synthesis (Yin 2009) then allowed us to identify common features of the cases, and to make more robust claims about emerging state-led integrated regional planning in the U.S.

\section{A New Model of State-Led Integrated Regional Planning In the US}

Despite declines in federal support, resistance from local governments, and an increasingly complex organizational environment, in recent years a handful of U.S. states empowered an entirely new set of regional planning programs that differ in important ways from those created in prior eras. The analysis of three states Indiana, New York and Michigan - shows similarities across the cases and also consistent contrasts with the older generation of regional planning organizations like RPCs and COPGs that still exist in these states. This newest era of regional planning has some important implications for the future of regional planning in the U.S. because of these programs' strong state involvement, their reorganization of regional planning organizations, and their redefined conception of both spatial and economic development planning. Table 2 outlines both the old and new regional planning organizations that exist in the states, and the rest of this section provides additional state-by-state descriptions of the newer organizations and programs. 
Table 2: Characteristics of old and new state-supported regional development planning organizations in Indiana, New York and Michigan

\begin{tabular}{|c|c|c|c|c|c|c|}
\hline & \multicolumn{2}{|c|}{ Indiana } & \multicolumn{2}{|c|}{ New York } & \multicolumn{2}{|c|}{ Michigan } \\
\hline & Old & New & Old & New & Old & New \\
\hline Names & $\begin{array}{l}\text { Various } \\
\text { (RPCs, COGs) }\end{array}$ & $\begin{array}{l}\text { Regional } \\
\text { Development } \\
\text { Agencies }\end{array}$ & $\begin{array}{l}\text { Regional } \\
\text { Councils, } \\
\text { Regional } \\
\text { Planning } \\
\text { Boards }\end{array}$ & $\begin{array}{l}\text { Regional } \\
\text { Economic } \\
\text { Development } \\
\text { Councils }\end{array}$ & $\begin{array}{l}\text { Various } \\
\text { (RPCs, COGs, } \\
\text { others) }\end{array}$ & $\begin{array}{l}\text { Regional } \\
\text { Prosperity } \\
\text { Collaboratives } \\
\text { / Councils / } \\
\text { Boards }\end{array}$ \\
\hline $\begin{array}{l}\text { Statewide } \\
\text { legislation }\end{array}$ & 1973,1981 & 2007 & 1960 & $\begin{array}{l}\text { None }(2011 \\
\text { executive } \\
\text { order) }\end{array}$ & 1945,1966 & 2014 \\
\hline $\begin{array}{l}\text { Number in } \\
2020\end{array}$ & 15 & 5 & 10 & 10 & 14 & 12 \\
\hline Extent & $\begin{array}{l}74 \text { of } 92 \\
\text { counties }\end{array}$ & 23 of 92 counties & $\begin{array}{l}47 \text { of } 62 \\
\text { counties }\end{array}$ & $\begin{array}{l}62 \text { of } 62 \\
\text { counties }\end{array}$ & $\begin{array}{l}83 \text { of } 83 \\
\text { counties }\end{array}$ & $\begin{array}{l}83 \text { of } 83 \\
\text { counties }\end{array}$ \\
\hline $\begin{array}{l}\text { Spatial } \\
\text { similarity }\end{array}$ & \multicolumn{2}{|c|}{ Similar but not exact } & \multicolumn{2}{|c|}{ Similar, but not exact } & \multicolumn{2}{|c|}{ Considerable reorganization } \\
\hline $\begin{array}{l}\text { Core } \\
\text { Functions }\end{array}$ & $\begin{array}{l}\text { Local } \\
\text { coordination, } \\
\text { preparation } \\
\text { of advisory } \\
\text { regional } \\
\text { development } \\
\text { plans }\end{array}$ & $\begin{array}{l}\text { Development of } \\
\text { regional plans, } \\
\text { oversight and } \\
\text { financing of major } \\
\text { projects }\end{array}$ & $\begin{array}{l}\text { Local } \\
\text { coordination, } \\
\text { joint service } \\
\text { provision, } \\
\text { advisory } \\
\text { regional } \\
\text { development } \\
\text { plans }\end{array}$ & $\begin{array}{l}\text { Coordination } \\
\text { of state } \\
\text { services, } \\
\text { application } \\
\text { for most } \\
\text { state } \\
\text { funding, plan } \\
\text { preparation }\end{array}$ & $\begin{array}{l}\text { Local } \\
\text { coordination, } \\
\text { preparation } \\
\text { of advisory } \\
\text { regional } \\
\text { development } \\
\text { plans }\end{array}$ & $\begin{array}{l}\text { Coordination } \\
\text { of state } \\
\text { services, local } \\
\text { coordination, } \\
\text { preparation of } \\
\text { development } \\
\text { plans }\end{array}$ \\
\hline $\begin{array}{l}\text { Fiscal } \\
\text { Authority }\end{array}$ & $\begin{array}{l}\text { Small (per- } \\
\text { capita) taxing } \\
\text { authority } \\
\text { after } 1981\end{array}$ & $\begin{array}{l}\text { Can issue bonds, } \\
\text { relatively larger } \\
\text { taxing authority (\% } \\
\text { of county income } \\
\text { tax) }\end{array}$ & $\begin{array}{l}\text { Small (per- } \\
\text { capita) taxing } \\
\text { authority }\end{array}$ & None & $\begin{array}{l}\text { Moderate, } \\
\text { access to } \\
\text { some } \\
\text { TIF/other } \\
\text { revenue w/ } \\
\text { consent of } \\
\text { member } \\
\text { counties }\end{array}$ & None \\
\hline $\begin{array}{l}\text { Funding from } \\
\text { state }\end{array}$ & Minimal & $\begin{array}{l}\$ 42 \mathrm{M} \text { to each of } 3 \\
\text { regions - single } \\
\text { grant round }\end{array}$ & Minimal & $\begin{array}{l}\$ 8.3 \text { Billion } \\
\text { (from 2011- } \\
19 \text { ) }\end{array}$ & $\begin{array}{l}\text { Up to } \$ 1 M \\
\text { total } \\
\text { statewide } \\
\text { annually }\end{array}$ & $\begin{array}{l}\text { Approx. \$2- } \\
\text { 3M statewide } \\
\text { annually } \\
(2014-2019)\end{array}$ \\
\hline $\begin{array}{l}\text { Administrative } \\
\text { (board) } \\
\text { structure }\end{array}$ & $\begin{array}{l}\text { Appointed by } \\
\text { member } \\
\text { municipalities } \\
\text { (variable size, } \\
\text { but usually } \\
\text { quite large) }\end{array}$ & $\begin{array}{l}\text { Small (5-person } \\
\text { boards) appointed } \\
\text { by member } \\
\text { municipalities }\end{array}$ & $\begin{array}{l}\text { Appointed by } \\
\text { member } \\
\text { municipalities } \\
\text { (variable size, } \\
\text { but usually } \\
\text { quite large) }\end{array}$ & $\begin{array}{l}\text { Roughly } 20 \\
\text { members, } \\
\text { appointed by } \\
\text { the Governor }\end{array}$ & $\begin{array}{l}\text { Appointed by } \\
\text { member } \\
\text { municipalities }\end{array}$ & $\begin{array}{l}\text { Made up of } \\
\text { specific } \\
\text { classes of } \\
\text { state-defined } \\
\text { stakeholders }\end{array}$ \\
\hline $\begin{array}{l}\text { Role of public } \\
\text { vs. private } \\
\text { sector }\end{array}$ & $\begin{array}{l}>2 / 3 \text { board } \\
\text { members } \\
\text { must be } \\
\text { public sector }\end{array}$ & $\begin{array}{l}\text { Public sector } \\
\text { officials/employees } \\
\text { barred from board }\end{array}$ & $\begin{array}{l}\text { No } \\
\text { requirement, } \\
\text { but } \\
\text { dominated by } \\
\text { public sector }\end{array}$ & $\begin{array}{l}\text { Private/non- } \\
\text { profit } \\
\text { dominated, } \\
\text { public sector } \\
\text { non-voting }\end{array}$ & $\begin{array}{l}\text { No } \\
\text { requirement, } \\
\text { but } \\
\text { dominated by } \\
\text { public sector }\end{array}$ & Both included \\
\hline $\begin{array}{l}\text { Role of older } \\
\text { orgs in new } \\
\text { ones }\end{array}$ & \multicolumn{2}{|c|}{$\begin{array}{l}\text { Some; though regional economic } \\
\text { development partnerships played a } \\
\text { larger role }\end{array}$} & \multicolumn{2}{|l|}{ Very little } & \multicolumn{2}{|c|}{$\begin{array}{l}\text { Some, though varied from } \\
\text { place to place }\end{array}$} \\
\hline
\end{tabular}


- Indiana's Regional Cities Initiative

The most recent chapter in a long history of regional planning in Indiana began with the 2005 passage of empowering legislation for a new form of regional organization: Regional Development Authorities (RDAs). Originally granted only to northwest Indiana, the legislature expanded the ability to create RDAs to the entire state in 2007 (Indiana Code § 36-7.5; Indiana Code § 36-7.6). The legislation gave groups of adjacent counties and the cities within them the power to voluntarily form an RDA with a mandate to create regional plans and finance and carry out large development projects (Indiana Code § 36-7.6-2-3). Unlike the board membership of Indiana's older Regional Planning Commissions, the five member RDA boards are much smaller and board members (jointly appointed by executives of the member counties) cannot be elected officials or employees of any municipality, so they are usually local private sector or non-profit leaders (Indiana Code § 36-7.6-2-7). RDAs are also eligible for proceeds from the county economic development income tax, a much larger pool of potential funds (Indiana Code § 36-7.6-4-2) than those available to previous types of regional entities. Most importantly, RDAs have the authority to issue bonds and thus implement elements of the plans they create (Indiana Code § 36-7.6-4-3).

Until 2014 only one RDA - the Northwestern Indiana RDA - existed. In that year, the legislature passed a bill directing the Indiana Economic Development Corporation (IEDC, the privatized replacement for the State Dept. of Commerce) to examine the role of Indiana's population centers in state-wide economic development (IEDC 2014). Following recommendations in the resulting report, the legislature created and funded the Regional Cities Initiative ( $\mathrm{RCl}$ ) in 2015. The RCl incentivized regional development planning through a competitive process that awarded funds to successful applicants. Entrants had to be sets of contiguous counties, but counties could determine their own regions. In order to receive funds, winning regions had to create an RDA to administer them.

In response, seven new regions submitted plans through the $\mathrm{RCl}$ that included specific projects and budgets. In only one was an older regional organization (an RPC) the lead actor, a six-county effort spearheaded by the Delaware-Muncie Metropolitan Plan Commission that did not win. In late 2015, the IEDC awarded $\$ 42$ million in matching funds to each of three winning regions: the Northeast, North-Central, and Southwest. Though not sufficient to fully fund all of the projects in each plan, it was far greater than the limited funding typically available to RPCs. RCl plans included a variety of projects including downtown development, infrastructure, and education, among others. In 2016, the IEDC also provided $\$ 150,000$ to the four nonwinning applicants to continue regional planning efforts (IEDC 2020). Of the three winners, only the NorthCentral effort under the leadership of the 501(c)(6) Michiana Partnership had any involvement from an older public sector regional organization, the Michiana Area Council of Governments. The other two efforts were spearheaded by 501(c)(6) regional partnerships: the Northeast Indiana Regional Partnership and Orthoworx in the northeast and the Development Commission of Southwest Indiana in the southwest (Southwest Indiana Regional Development Authority 2015; Northeast Indiana Regional Partnership and Greater Fort Wayne, Inc. 2015; Regional Cities of Northern Indiana 2015).

\section{- New York's Regional Economic Development Councils}

Upon taking office in 2011, Governor Andrew Cuomo created New York's Regional Economic Development Councils (REDCs) and divided the state up into ten development regions. REDCs are publicprivate partnerships co-chaired by a regional business leader and the head of an institution of higher education in the respective region. Roughly 20 additional council members representing businesses, trade groups and large not-for-profit organizations are appointed by the governor. Selected county and municipal government leaders serve as non-voting ex-officio members. The state's economic development agency, Empire State Development (ESD), provides administrative and technical assistance to the REDCs through ESD offices located in each region with additional support from the New York Department of State. Their original 2011 mandate tasked the REDCs with developing 5-year strategic plans identifying specific projects that the state would consider for funding. That year the state awarded $\$ 785$ million across all ten councils, ranging from $\$ 103.7$ million in the Central region to $\$ 60.2$ million for the Mohawk Valley region (New York State 2011). To 
date the REDC program's nine funding rounds have awarded $\$ 8.3$ billion to over 8,300 projects, including $\$ 761$ million in 2019 (New York State 2019a, New York State 2019b).

Alongside the REDCs, New York also created a new Consolidated Funding Application (CFA) for state funds, a gateway to over 30 grant programs from 11 state agencies, allowing REDCs to access multiple revenue sources through a single application. Additionally, the REDC can designate specific projects in the CFA as Priority Projects if they conform to the goals and strategies of the regional strategic plans. Priority Projects receive preferential treatment in the application process.

Though economic development is the clear focus of the ten regional plans, the approach is relatively holistic. Significant attention is paid to revitalizing urban centers, protecting natural landscapes and resources, funding arts and cultural programs, eliminating poverty, providing affordable housing, and addressing climatechange related impacts. In 2015, the state launched the Upstate Revitalization Initiative (URI), a \$1.5 billion initiative wherein the state's seven upstate REDC regions were required to add a "Revitalization Plan" to their annual progress reports. Based on those plans, three regions ultimately received $\$ 500$ million each, spread over five years, for economic development, community development and job creation programs (New York State 2015). Physical planning is also an element of these efforts, with the URI application materials promoting smart growth and healthy urban centers as key principles. In 2016, the state added the Downtown Revitalization Initiative to the REDC process, committing an additional $\$ 100$ million to revitalize 10 downtowns across the state in each funding cycle, with 30 municipalities each receiving $\$ 10$ million grants to date (New York State 2019c). The general outline of the REDC program also helped to inform New York State's community recovery planning efforts after Superstorm Sandy in 2012, with the New York Rising Community Reconstruction (NYRCR) planning process (Finn et al. 2019)

\section{- Michigan's Prosperity Regions}

The latest stage in the evolution of Michigan's regional planning structure came in 2013 when then Governor Rick Snyder announced that state's Regional Prosperity Initiative (RPI), a program designed to streamline strategic planning, resource allocation, and service delivery across state agencies while simultaneously promoting regional development planning (Michigan Dept. of Technology, Management, and Budget 2020a). The program created twelve new "Prosperity Regions" that redrew the state's 14 older State Planning and Development Regions (SPDRs), each of which had been represented by their own regional planning entity (e.g. a COG or RPC). It also established an annual grant program for regional development planning with one grant available per Prosperity Region. The grant program was open exclusively to the 14 SPDR regional councils and the state's 16 MPOs, but only if they formed new collaborative organizations whose operational boundaries were coterminous with the new Prosperity Regions. The new entities had to include representation from multiple public, private and nonprofit sector stakeholders as well as specific representation from adult education, community development, economic development, transportation, higher education and workforce development interests (Michigan Dept. of Technology, Management, and Budget 2017).

The new regional organizations could be one of three defined types that differed in the degree of formality of their structure, with more formal structures eligible for larger grants. The lowest level, Collaboratives, need only show adequate stakeholder representation to be eligible for up to $\$ 250,000$ in annual grants. Councils, the second level, must have "shared administrative services and an executive governing entity as demonstrated by a formal local agreement" and are eligible for up to $\$ 375,000$ annually. Boards, the highest level, require the merger of all of the region's existing MPOs, SPDR councils, workforce development boards and EDDs into a single entity eligible for up to $\$ 500,000$ annually. Higher levels were also required to prepare more detailed plans. A state budget allocation of $\$ 2.5$ million funded the RPI in its first year (FY 2014). Subsequent allocations averaged \$2.5 to \$3 million (Michigan Dept. of Technology, Management, and Budget 2020b). After six years, funding for the Regional Prosperity Initiative was suspended in 2020. 
The intended geographic and organizational restructuring has not come easily, though nearly every region has received funding in every year of the program. After six years of funding there is only one Board, one Council, and ten Collaboratives (the lowest level). Eleven of the twelve grantees in 2017 were the old SPDR lead organizations, and the twelfth was a metropolitan council (the sole example of yet another type of regional organization that the state had empowered in 1989). With boundary changes, some RPI grantees have had to prepare RPI plans for different regions than those in which they have historically operated. Three regional councils have been shut out entirely by the reorganization between old and new regions. As in the other states, RPI plans were often quite broad in terms of the issues addressed, while being nominally focused on economic development. The Networks Northwest Regional Prosperity Board, for example, created ten different interconnected plans focusing on issues including arts and culture, energy, workforce, housing, transportation, and healthy communities.

\section{Cross-cutting Themes}

All three of these programs emerged in the last decade, and taken together they represent a wholesale reconstruction of state-led regional development planning in the U.S. Table 2 outlines consistent similarities between them as well as the ways in which they differ from older organizations in the same states. In this section, we discuss the five most salient cross-cutting themes that emerge from the cases, which are summarized in Table 3.

Table 3: Major themes in re-invention of state-led regional planning in the U.S.

\begin{tabular}{|l|lll|}
\multicolumn{1}{l}{ Theme } & Late 20th Century Model & $\rightarrow \rightarrow$ & Emergent Model \\
\hline $\begin{array}{l}\text { Organization and } \\
\text { Funding }\end{array}$ & $\begin{array}{l}\text { Mostly RPCs and COGs, little } \\
\text { funding from state }\end{array}$ & $\rightarrow \rightarrow \begin{array}{l}\text { New organizations, often new } \\
\text { regional boundaries, significant } \\
\text { funding }\end{array}$ \\
\hline Leadership & Public-sector dominated & $\rightarrow \rightarrow$ & Private-sector dominated \\
\hline Development Focus & $\begin{array}{l}\text { Management of growth and } \\
\text { orderly development }\end{array}$ & $\rightarrow \rightarrow$ & Pro-development/revitalization \\
\hline Planning Approach & $\begin{array}{l}\text { Regional coordination through } \\
\text { creation of advisory plans }\end{array}$ & $\rightarrow \rightarrow$ & $\begin{array}{l}\text { Strategic planning aimed at } \\
\text { identifying specific projects }\end{array}$ \\
\hline $\begin{array}{l}\text { Efficient State Service } \\
\text { Delivery }\end{array}$ & Not an explicit goal & $\rightarrow \rightarrow$ & Explicit goal (in 2 of 3 cases) \\
\hline
\end{tabular}

First, all three states have created an entirely new form of regional planning organization, despite the continued presence of older regional planning and development organizations like RPCs, COGs, MPOs, etc. The new organizations have access to new, larger funding streams that were unavailable to the older generation of organizations. In New York, the REDCs have coordinated the application for, and delivery of, billions of dollars through the NY Consolidated Funding Application in less than a decade. This moved REDCs to the center of some of the largest funding decisions in the state. In Indiana, older regional organizations could access only a small per-capita tax collected by counties, but the newer RDAs have bonding authority as well as access to a larger pool of income tax revenue. Even in Michigan, where the newer organizations were not as powerful as in New York and Indiana, the RPI incentivized the creation of new organizations by consistently providing more annual funding than it had to the older organizations.

Second, all three states expanded the roles and powers of the private sector in the governance of the new organizations. In New York, local elected officials serve on REDCs in non-voting ex-officio roles only, but voting members are drawn from the private, non-profit, and education sectors, with the largest share going to 
the private sector (Green and Finn 2019). In Indiana, older RPC boards were required to include at least twothirds elected officials, but such officials were expressly prohibited from serving on the newer RDA boards. The majority of RDA board members represent the private sector. In all three states, regional economic development partnerships were at least equally, if not more involved in the new organizations than older regional planning organizations.

Third, all three of these new programs were justified, not just as a means to coordinate regional decisions and investments as in prior eras, but as an explicit means to promote development of the region (and thus the state, collectively). Michigan's RPI aimed "to create vibrant regional economies" (Michigan Dept. of Technology, Management, and Budget 2020a). The Indiana RCl intended to "transform their regions into nationally-recognized destinations to live, work and play" (IEDC 2020). New York "replaced the 'one-size fits all' approach to economic growth with a 'ground-up' strategy that focuses on cooperation and investing in regional assets to generate opportunity" (NY State n.d.). These justifications differ strongly from the purpose of older organizations. For example, Indiana's RPCs were intended to "coordinate the planning programs of all units and the state [ ... ] in an advisory capacity only" (Ind. Code § 36-7-7-7(a)). They differ even more from regional planning efforts in states like Oregon and Florida aimed at controlling growth and its negative effects. The newer programs were more concerned with promoting development than managing it. Though "economic development" was a common thread across all three programs, the approaches taken thus far address a broader set of policy areas including site development, downtown revitalization, affordable housing, transportation, resource preservation, workforce development and education, and quality-of-life, among other goals. These are more diverse than the business attraction, creation, retention, and expansion efforts that still dominate economic development practice, and many have a clear connection to longstanding regional spatial planning concerns.

Fourth, and related to the last point, the three states have adopted a very different approach to regional planning than they did in prior eras. Specifically, they eschew overt attempts to affect regulation as a means of impacting spatial development. Though most RPCs and COGs could and did develop regional plans, as noted above, they were advisory in most cases. This earlier compromise between state lawmakers and local governments allowed older regional planning organizations to consider and propose various land development patterns without binding local government to action through the passage of enforceable ordinances. In contrast, the new organizations represent a different compromise between state and local governments, namely that the latter would accept powerful regional planning organizations over which they had little control so long as those organizations served primarily to direct resources to the region. The result is a more powerful type of regional planning organization that still leaves local governments in control of land use regulation. The planning undertaken by the newer organizations consists primarily of large-scale visioning, agenda-setting, and identification of specific projects and programs to spur development over a wide set of policy areas. Though such planning might seem hopelessly weak as a means of addressing the effects of runaway growth currently overtaking parts of the U.S. south and west, it may serve a useful purpose in regions more focused on revitalization.

Fifth, while efficiency in the provision of state programs has always been one motivation for regional organizations broadly, in two of the three programs (New York and Michigan) it emerged as a primary goal of the new effort. Prior efforts seemed to assume that the creation of regional organizations would somehow spur coordination and streamline services. In contrast, Michigan explicitly cited efficiency of state service provision in their rationale for creating the RPI, referring to the state's prior agency service administration map as the "spaghetti map" due to the multiple different sets of regions adopted by different agencies. The RPI also set out an explicit list of which organizations and stakeholders had to be involved in the new organizations rather than leaving it up to local leaders to decide. New York's Consolidated Funding Application is similarly aimed at more efficiency in allocating capital funds, accomplished by channeling dozens of state programs through a single set of regional organizations and a single application process that allows applicants to apply to multiple agencies for funding for a single project. 


\section{Implications for State-led Regional Planning}

While the popularity of regional planning waxed and waned over the last century in the U.S., the idea continues to find support from policymakers. Various forms of regional cooperation or coordination can be found throughout the U.S. (Dabson 2019; Miller and Nelles 2020). The more expansive state-led programs analyzed here represent a novel approach to the design and implementation of regional development planning. Though the programs are relatively new, they illustrate some ideas for how regional planning might be re-imagined over the coming decades. At the same time, they may raise concerns about the growing influence of less accountable private sector interests in regional governance broadly. We outline three main takeaways for those considering implementing or redesigning regional planning programs at the state level.

First, these examples show that the relative lack of general-purpose government bodies at the regional scale in the U.S. continues to provide a space for states to experiment with different organizational forms, powers, and mandates. While the new organizations here still represent a compromise between state and local leaders, the nature of that compromise is quite different than in prior models. These states have shown that governing arrangements can be rethought rather freely at the regional scale, and that regional planning authority need not necessarily be vested in older regional planning organizations, particularly given how the latter have evolved over the past decades. Regional boundaries, too, can be repurposed for new programs or entirely redrawn. The relative uncertainty and mutability of regional boundaries allows them to be redrawn to reflect changing patterns of people, industries, and politics. These examples suggest that regional development planning is only as weak and uninspired as states allow regional planning programs and organizations to become.

Second, these efforts highlight the fact that some states are willing to put significant resources behind a form of regional development planning that integrates spatial planning, economic development planning, and capital project planning. In seeking to address issues as varied as land development, transportation, resource preservation and development, housing provision, employment and education, this approach understands planning as more than land use regulation. Piro et al. (2017) call this "integrated planning" and highlight it as a key hallmark of effective regional planning. In supporting this type of approach, and in providing significant funding for planning and implementation, these states have provided regions the resources and freedom to engage in more visionary agenda setting and transformative projects. Even the case of Michigan, which provided the least funds for project implementation, shows this approach can have positive regional effects. As Chakraborty (2010) suggests, participation in planning processes - even in the absence of binding policy outcomes - can positively affect regional governance by building relationships, capacity, and trust across jurisdictional boundaries, thereby creating a space in which these larger transformative projects can be incubated and nurtured. In Southwest Michigan, for example, the RPI planning process provided an opportunity to develop the Kalamazoo River Valley Trail (KRVT) Extension, an 8 mile long non-motorized trail in Kalamazoo County that will connect two existing spurs and create a 30 mile long KRV trail network that in turn helps complete a dedicated trail across southern Michigan (Southwest Michigan Prosperity Region 2014). The protracted, multi-agency, multi-jurisdiction planning processes needed to develop these kinds of projects can be very difficult to sustain without state coordination and funding to support them. State-led and state-funded integrated planning processes can provide both the incentive of resources and the basic structure for planning that is sometimes necessary to overcome the friction inherent in situations of fragmented governance.

Lastly, the programs suggest that there is real interest in addressing modern regional challenges with organizations governed by boards that minimize the power of the public sector in favor of a broad set of private and non-profit sector actors. Civic efforts such as Envision Utah, as well as much older regional planning examples such as the early 20th century Chicago and New York plans, provide a model in which the businesses, non-profits, civic leaders, and state and local governments all play a role in regional decision making. In this light, the public-sector dominated RPCs and COGs that led regional planning in the last century appear as outliers in an ongoing process of evolution. The new organizations analyzed here lack the power of land use regulation, but they may benefit from a wider range of views and capacities than can be found among boards dominated by local elected officials. There is one important caution to this new approach, however. The 
new boards do not merely include private and non-profit sector leaders, but rather grant significant government fiscal authority to them. This is different from prior civic-led efforts, and while it may lead to more empowered and nimble regional planning, that may come with far less public oversight and accountability.

\section{Conclusion}

The state led integrated regional planning programs developed in Indiana, New York and Michigan in the last decade help illustrate how states can begin to reconstitute the practice of regional planning in the twenty-first century with a focus on modern challenges and opportunities. These programs bear watching to better understand the merits of this emerging approach. Further research must examine whether the plans and projects produced by these programs are successful at facilitating and sustaining coordinated action across regions and avoiding the political pitfalls that have befallen prior attempts at regional planning, all while still embodying the broader public interest.

\section{References}

Abels, Michael. 2014. "Strategic alignment for the new normal: Collaboration, sustainability, and deliberation in local government across boundaries." State and Local Government Review 46(3): 211-218.

Abbott, Carl. 1997. "The Portland region: Where city and suburbs talk to each other-and often agree." Housing Policy Debate 8(1): 11-51.

Bowman, Ann O'M. and James L. Franke. 1984. "The decline of substate regionalism." Journal of Urban Affairs 6(4): 51-63.

Bureau of Transportation Statistics, U. S. Dept. of Transportation. 2015. State transportation statistics 2015. Washington, DC: U.S. Department of Transportation.

Burnham, Edward H. and Edward Herbert Bennett. 1909. Plan of Chicago. Chicago, IL: Commercial Club of Chicago.

Chakraborty, Arnab. 2010. "Scenario planning for effective regional governance: Promises and limitations." State and Local Government Review 42(2): 156-167.

Chapin, Timothy S. 2012. "Introduction: From Growth Controls, to Comprehensive Planning, to Smart Growth: Planning's Emerging Fourth Wave." Journal of the American Planning Association 78(1): 5-15.

Committee on Regional Plan of New York and its Environs. 1929. Regional plan of New York and its environs. Philadelphia, PA: Wm. F. Fell Co. Printers.

Dabson, Brian. 2019. “Regional Solutions for Rural and Urban Challenges." State and Local Government Review 51(4): 283-291.

Envision Utah. (2016). “Envision Utah: Mission and history." Available at: https://www.envisionutah.org/about/mission-history

Finn, Donovan, Divya Chandrasekhar and Yu Xiao. 2019. "A region recovers: Planning for resilience after superstorm Sandy." Journal of Planning Education and Research. Online preprint: $0739456 \times 19864145$.

Fishman, Robert. 2000. "The death and life of American regional planning." Reflections on Regionalism, edited by Bruce Katz, 107-126. Washington, DC: Brookings Institution Press.

Friedmann, John, and Robin Bloch. 1990. “American exceptionalism in regional planning, 1933-2001." International Journal of Urban and Regional Research 14(4): 576-601.

Friedmann, John and Clyde Weaver. 1979. Territory and function: The evolution of regional planning. Berkeley: University of California Press.

Frug, Gerald E. and David J. Barron. 2008. City bound: How states stifle urban innovation. Ithaca, NY: Cornell University Press.

Green, Timothy. 2016. "The relationship between formal analysis and regional marketing: Evidence from a national survey of regional economic development partnerships." Regional Studies Association Second North America Conference, Atlanta, GA. 
Green, Timothy and Donovan Finn. 2019. "Collaborative governance or private sector power grab? An analysis of the changed governance of regional development planning in three U.S. states." Association of Collegiate Schools of Planning 59th Annual Conference, Greenville, SC.

Grigsby III, J. Eugene 2003. "Regional governance and regional councils." Regional government innovations: A handbook for citizens and public officials, edited by Roger L. Kemp, 287-293. Jefferson, NC: Mcfarland and Company, Inc.

Hanlon, Bernadette, John Rennie Short, and Thomas J. Vicino. 2009. Cities and suburbs: New metropolitan realities in the US. London and New York: Routledge, Taylor and Francis Group.

Hansen, Niles, Benjamin Higgins, and Donald J. Savoie. 1990. Regional policy in a changing world. New York: Plenum Press.

Indiana Economic Development Corporation. 2014. Benchmarking U.S. regional cities: A study and guide for transformation. Indiana Economic Development Corporation.

Indiana Economic Development Corporation. 2020. “What is the regional cities initiative?" Available at: https://www.iedc.in.gov/programs/regional-cities-initiative/home

Julnes, George and Wolfgang Pindur. 1994. "Determinants of local governmental support for alternative forms of regional coordination." The American Review of Public Administration 24(4): 411-428.

Lewis, Rebecca and Gerrit-Jan Knaap. 2012. "Institutional structures for state growth management: An examination of state development plans." State and Local Government Review 44(1): 33-44.

Meck, Suart. 2002. Growing Smart Legislative Guidebook: Model Statutes for Planning and the Management of Change. Chicago: American Planning Association.

Michigan Dept. of Technology, Management, and Budget. 2017. "Regional prosperity initiative fiscal year 2018 evaluation criteria." Available at: https://www.michigan.gov/documents/dtmb/Evaluation 437058 7.pdf

Michigan Dept. of Technology, Management, and Budget. 2020a. "Regional prosperity initiative - the basics." Available at: https://www.michigan.gov/dtmb/0,5552,7-358-82547_56345_66155-310319-,00.html

Michigan Dept. of Technology, Management, and Budget. 2020b. "Regional prosperity initiative grant recipients." Available at: https://www.michigan.gov/dtmb/0,5552,7-358-82547_56345_66155--,00.html

Miller, David, and Jen Nelles. 2020. "Order out of chaos: The case for a new conceptualization of the crossboundary instruments of American regionalism." Urban Affairs Review 56(1): 325-359.

Mogulof, Melvin B. 1971. "Regional planning, clearances and evaluation: A look at the A-95 process." Journal of the American Institute of Planners 37(6): 418-422.

Morrill, Richard L. 1989. “Regional governance in the United States: For whom?” Environment and Planning C: Government and Policy 7(1): 13-26.

New York State. No Date. "Regional economic development councils - about us." Available at: https://regionalcouncils.ny.gov/about.

New York State. 2011. "Governor Cuomo Announces \$785 Million in Economic Development Funding Through Regional Councils, December 8, 2011." Available at: https://www.governor.ny.gov/news/governorcuomo-announces-785-million-economic-development-funding-through-regional-councils.

New York State. 2014. “2014 Regional Economic Development Council Awards.” Available at https://regionalcouncils.ny.gov/sites/default/files/2018-02/REDCAwardsBooklet2014.pdf.

New York State. 2015. “Governor Cuomo Announces More Than \$2 Billion in Economic Development Resources Awarded Through Upstate Revitalization Initiative and Regional Economic Development Council Competition, December 10, 2015." Available at: https://www.governor.ny.gov/news/governorcuomo-announces-more-2-billion-economic-development-resources-awarded-through-upstate.

New York State. 2019a. "Providing the Tools for Prosperity." Available at: https://regionalcouncils.ny.gov/sites/default/files/2019-04/2019REDCGuidebook.pdf. 
New York State. 2019b. "Regional Economic Development Councils: 2019 Awards.” Available at: https://www.ny.gov/sites/ny.gov/files/atoms/files/2019REDCA2f79hkFinal.pdf.

New York State. 2019c. "Governor Cuomo and Legislative Leaders Announce FY 2020 Enacted Budget Includes \$100 Million for Fourth Round of Downtown Revitalization Initiative, April 19, 2019.” Available at: https://www.governor.ny.gov/news/governor-cuomo-and-legislative-leaders-announce-fy2020-enacted-budget-includes-100-million.

Northeast Indiana Regional Partnership and Greater Fort Wayne, Inc. 2015. "The road to one million: Northeast Indiana regional cities initiative proposal." Available at: https://assets.neindiana.com/resources/theroad-to-one-million-plan.pdf.

Olberding, Julie Cencula. 2002. “Diving into the 'third waves' of regional governance and economic development strategies: A study of regional partnerships for economic development in U.S. metropolitan areas." Economic Development Quarterly 16(3): 251-272.

Orfield, Myron. 1997. Metropolitics: A regional plan for community and stability. Washington, DC: Brookings Institution Press.

Pelham, Thomas G. 2017. "A historical perspective for evaluating Florida's evolving growth management process." In Growth management in Florida: Planning for paradise, edited by Timothy Stewart Chapin, Charles E. Connerly, and Harrison T. Higgins. London and New York: Routledge.

Piro, Rocky, Robert Leiter, and Sharon Rooney. 2017. Emerging trends in regional planning. Planning Advisory Service Report 586. Chicago: American Planning Association.

Regional Cities of Northern Indiana. 2015. “Innovate Indiana Regional Development Plan.” Available at https://iedc.in.gov/docs/default-source/iedc-assets/regional-cities/innovate-indiana northern-inregional-development-plan-2015-371-pgs.pdf?sfvrsn=4.

Renski, Henry. 2009. "A New Era of Federal Involvement in Regional Economic Development? The Case of the Wired Initiative." Environment and Planning C: Government and Policy 27(4): 593-611.

Rothblatt, Donald N. 1994. "North American metropolitan planning." Journal of the American Planning Association 60(4): 501-520.

Seltzer, Ethan and Armando Carbonell. 2011. "Planning Regions." In Regional planning in America: Practice and prospect, edited by Ethan Seltzer and Armando, 1-16. Cambridge, MA: Lincoln Institute of Land Policy.

Southwest Indiana Regional Development Authority. 2015. “Indiana's great southwest regional development plan." Available at: https://www.iedc.in.gov/docs/default-source/iedc-assets/regionalcities/southwestern-indiana-rda-regional-development-plan-application upload-2-220pgs.pdf?sfvrsn=12c142d1 6 .

Southwest Michigan Prosperity Region. 2014. “5 Year Prosperity Plan, Volume 2.” Available at: https://www.swmpc.org/downloads/rpivolume2110315final.pdf.

U.S. Department of Commerce. 1928. “A standard city planning enabling act.” Washington, DC: U.S. Government Printing Office.

Wallis, Allan D. 1992. “New life for regionalism? Maybe." National Civic Review 81(1): 19-26.

Weitz, Jerry, and Ethan Seltzer. 1998. "Regional planning and regional governance in the United States 19791996." Journal of Planning Literature 12(3): 361-392.

Wheeler, Stephen M. 2000. "Planning for metropolitan sustainability." Journal of Planning Education and Research 20(2): 133-145.

Whisman, Holly Erin Cooper. 2013. "Regional councils and the influence of state laws on regional governance." PhD diss. University of North Carolina at Charlotte. ProQuest 3608510.

Yin, Robert K. 2009. Case Study Research Design and Methods, Fourth Edition. Applied Social Research Methods Series, Vol. 5. Los Angeles, CA: Sage. 